\title{
Effects of a Combined Biological Restoration Technology on Nitrogen and Phosphorus Removal from Eutrophic Water
}

\author{
Long Wang ${ }^{1,2}$, Jian Sun ${ }^{1,2}$, Wenping Zheng', ${ }^{1,}$ Tao Huang, ${ }^{1,2}$ \\ Yi Zhang ${ }^{1}$, Zhenbin Wu ${ }^{1}$, Feng $\mathrm{He}^{1 *}$ \\ ${ }^{1}$ State Key Laboratory of Freshwater Ecology and Biotechnology, Institute of Hydrobiology, \\ Chinese Academy of Sciences, Wuhan, China \\ ${ }^{2}$ University of Chinese Academy of Sciences, Beijing, China
}

Received: 2 August 2017

Accepted: 21 September 2017

\begin{abstract}
For this study we applied a biological restoration technology combined with introducing filterfeeding bivalves (Hyriopsis cumingii), stocking planktivorous fish (silver carp), and replanting submerged macrophytes (Ceratophyllum demersum L.) in order to treat eutrophic water. The effects of this combined biological restoration measure on remedying eutrophic water were investigated, and the main mechanisms of this combined measure for nutrient transportation and transformation were revealed. The results showed this combined biological restoration measure effectively reduced nutrient nitrogen $(\mathrm{N})$ and phosphorus (P) loads in the water. The assimilation and absorption of submerged macrophytes and the nutrient transformation from water to the sediments were the main mechanisms for water $\mathrm{N}$ and $\mathrm{P}$ removal. In conclusion, the combination of different biological restoration measures may be a potential choice for water managers in eutrophic water restoration.
\end{abstract}

Keywords: eutrophication, combined biological restoration, biomanipulation, nitrogen, phosphorus

\section{Introduction}

Eutrophication resulting from high nutrient load has been a major environmental issue worldwide. Many biological restoration methods have been developed to remedy eutrophic waterbodies [1-2]. Among them, stocking planktivorous fish such as filter-feeding silver carp or bighead carp, has been proved to be effective in controlling blue-green algae blooms [3]. And

*e-mail: hefeng@ihb.ac.cn introducing filter-feeding bivalves into water is also applied to control algal overgrowth [4]. In addition, the replanting of submerged macrophytes is often used to stabilize the clear-water state [5-6]. However, many unsuccessful attempts have suggested that using only a single biomanipulation measure fails to reduce internal nutrient load sufficiently, which results in a high probability that the site will return to a turbid state some years after successful restoration [7-9]. For example, stocking filter-feeding fish or bivalves will promote the nutrient release from sediment into the water [10-11]. In addition, the grazing effects of silver carp or bivalves could promote the miniaturization of 
phytoplankton community structure, thereby leading to an increase of total phytoplankton primary productivity [8]. Accordingly, many researchers have suggested that combined biological restoration approaches, which could not only improve water quality in the short term, but also maintain long-term stability, may be a better choice for water managers to remedy eutrophic waterbodies [2, 12].

Reducing external and internal nutrient loads is an important factor for determining the success of lake ecological restoration [13-15]. The roles of aquatic organisms for nutrient removal in a single biomanipulation measure have been studied widely. Stocking silver carp or bivalves could promote the transportation of nutrients from water to sediments through grazing, assimilation, and biodeposition of suspended particles. Meanwhile, many researchers have suggested that silver carp and bivalves could also promote nutrient regeneration through bioturbation [1617]. Submerged macrophytes, which are an important part of the biological community, could assimilate and absorb nutrients from water and sediments [1819]. However, the decomposition of dead macrophytes will promote the increase of water nutrient content. In addition, microorganisms can decompose and metabolize nutrients in water. The extracellular enzyme activity reflects the power and strength of various biochemical processes in the sediments, which has vital significance for material circulation in ecological systems [20-22]. However, few investigations have revealed the roles of these aquatic organisms for nutrient removal in a combined biological restoration measure. Therefore, it is necessary to reveal the main mechanisms of nutrient removal in the combined biological restoration measures.

Accordingly, our experiment designed a stereoscopic combined biological restoration measure that can be used not only to control the algal biomass by stocking silver carp and bivalves (Hyriopsis cumingii) at the pelagic and benthic of the water column, but also to reduce nutrients by replanting submerged macrophytes (Ceratophyllum demersum L.). Meanwhile, a field simulation experiment was conducted to (1) investigate the effects of this combined biological restoration measure on remedying eutrophic waterbodies and (2) to reveal the main mechanisms of this combined biological restoration measure for nutrient transport and transformation. This study can provide a reference for water managers when applying combined biological restoration measures to remedy eutrophic waterbodies.

\section{Materials and Methods}

\section{Experimental Systems}

This experiment was performed in the field from September to October 2016 in Wuhan City, Hubei Province, China. Eight systems were set up using
Table 1. Basic property of experimental water and sediments.

\begin{tabular}{|c|c|c|c|}
\hline \multicolumn{2}{|c|}{ Water } & \multicolumn{2}{c|}{ Sediments } \\
\hline $\mathrm{TP}$ & $0.514 \pm 0.004(\mathrm{mg} / \mathrm{L})$ & $\mathrm{TP}$ & $1.360 \pm 0.124(\mathrm{~g} / \mathrm{kg})$ \\
\hline $\mathrm{PO}_{4}{ }^{3-} \mathrm{-P}$ & $0.048 \pm 0.001(\mathrm{mg} / \mathrm{L})$ & $\mathrm{TN}$ & $3.244 \pm 0.273(\mathrm{~g} / \mathrm{kg})$ \\
\hline $\mathrm{TN}$ & $5.177 \pm 0.068(\mathrm{mg} / \mathrm{L})$ & - & - \\
\hline $\mathrm{NH}_{4}^{+}-\mathrm{N}$ & $0.476 \pm 0.078(\mathrm{mg} / \mathrm{L})$ & - & - \\
\hline $\mathrm{NO}_{3}-\mathrm{N}$ & $0.520 \pm 0.004(\mathrm{mg} / \mathrm{L})$ & - & - \\
\hline $\mathrm{NO}_{2}-\mathrm{N}$ & $0.055 \pm 0.029(\mathrm{mg} / \mathrm{L})$ & - & - \\
\hline $\mathrm{Chl}-\mathrm{a}$ & $247.42 \pm 20.58(\mu \mathrm{g} / \mathrm{L})$ & - & - \\
\hline
\end{tabular}

concrete tanks $(1 \times 1 \times 1 \mathrm{~m})$ in this experiment. Meanwhile, a rain-proof shelter was constructed using translucent corrugated plastic, approximately $2 \mathrm{~m}$ above the experimental systems. The experimental light and temperature conditions were maintained to be consistent with the local natural light and temperature, and so were gradually reduced from an average of $26.5^{\circ} \mathrm{C}$ to an average of $23.2^{\circ} \mathrm{C}$. In each system, $15-\mathrm{cm}$-thick layers of sediments and 75-cm-deep layers of water were added and equilibrated for 3 weeks. The water and sediments were both collected from a nearby eutrophic fishfarming pond, which is part of Donghu Lake, where serious water blooms appear in spring and fall annually. The sediments were completely mixed before being placed into the experimental system. The basic properties of experimental water and sediments are shown in Table 1. Then these 8 simulation systems were divided into 2 experimental groups named control and combined treatment group, with each group having 4 duplicates. The combined biological restoration group was stocked with silver carp and bivalves and replanted with submerged macrophytes. Their biomasses are shown in Table 2. The control group did not add any aquatic organisms.

The triangle sail mussel (mean length $\sim 10 \mathrm{~cm}$, mean wet weight $\sim 90 \mathrm{~g}$ ) and silver carp (mean length $\sim 15 \mathrm{~cm}$, mean wet weight $\sim 62 \mathrm{~g}$ ) were purchased from a mussel breeding site in Wuhan. Ceratophyllum demersum L. was collected from Donghu Lake located in Wuhan. The mean length of Ceratophyllum demersum L. specimens used was approximately $25 \mathrm{~cm}$. All the aquatic organisms were pre-cultured for 2 weeks using water collected from the pond from which the experimental water and sediments were collected. To reduce the impact of external nutrient load we did not add any food for the fish or bivalves into the experimental systems during the experiment.

\section{Sampling and Analysis}

Every seven days a clean bottle was used to collect $2.0 \mathrm{~L}$ water samples from each system, $500 \mathrm{~mL}$ of which were used to determine the concentrations of chlorophyll 
Table 2. Settings of each experimental treatment group.

\begin{tabular}{|c|c|c|c|c|c|c|}
\hline \multirow{2}{*}{ Treatments } & \multicolumn{2}{|c|}{ Hyriopsis cumingii } & \multicolumn{2}{c|}{ Silver carp } & \multicolumn{2}{c|}{ Ceratophyllum demersum L. } \\
\cline { 2 - 7 } & Number (ind.) & Weight $(\mathrm{g})$ & Number (ind.) & Weight $(\mathrm{g})$ & Weight $(\mathrm{g})$ & Coverage \\
\hline Control & 0 & 0 & 0 & 0 & 0 & 0 \\
\hline Combined & 4 & $363.9 \pm 10.6$ & 1 & $62.0 \pm 14.6$ & $200 \pm 5$ & $30 \%$ \\
\hline
\end{tabular}

a (chl a) after filtration through Whatman GF/C glass filters $(1.2 \mu \mathrm{m})$ and a $24 \mathrm{~h}$ extraction with $90 \%$ acetone. The rest was used to assess the concentrations of total phosphorus (TP), orthophosphate $\left(\mathrm{PO}_{4}^{3-}-\mathrm{P}\right)$, total nitrogen $(\mathrm{TN})$, ammonia nitrogen $\left(\mathrm{NH}_{4}^{+}-\mathrm{N}\right)$, nitrate $\left(\mathrm{NO}_{3}^{-}-\mathrm{N}\right)$, and nitrite $\left(\mathrm{NO}_{2}^{-}-\mathrm{N}\right)$ in water. Temperature, $\mathrm{pH}$, and oxidation-reduction potential were also determined using a portable Multimeter (Thermo ORION 5-STAR).

Before and after the experiment, the sediment samples were taken from the macrophyte root zone. The sediment samples were divided into three portions: a major portion was used to extract pore water samples by centrifuge at 5,000 rpm for $20 \mathrm{~min}$; another was used to determinate dehydrogenase, urease, and phosphatase activity; and the remainder was naturally air-dried and sieved with a standard 100-mesh sieve.

All these chemical characteristics were analyzed according to the Standard Methods of Environment Monitoring in China [23].

\section{Data Analysis}

One-way ANOVA tests were performed to determine significant differences of water quality parameters between treatments. Non-parametric tests (Kruskal-Wallis test) were used when the data distribution was skewed, with $P<0.05$ considered significant. All the figures were drawn with Origin 8.0. The analyses were finished with SPSS 20.0 for windows.

\section{Results}

By the end of the experiment the fresh weight of submerged macrophytes in the combined treatments increased from $200 \mathrm{~g}$ to more than $1,100 \mathrm{~g}$. The final coverage of submerged macrophytes reached $100 \%$. The body weights of some silver carp and bivalves slightly decreased but the survival status was good.

\section{Changes in Different Forms of $\mathrm{N}$ and P Contents in the Overlying Water}

The results showed that there were significant changes in $\mathrm{TP}, \mathrm{PO}_{4}^{3-}-\mathrm{P}, \mathrm{TN}, \mathrm{NH}_{4}^{+}-\mathrm{N}, \mathrm{NO}_{3}^{-}-\mathrm{N}$, and $\mathrm{NO}_{2}^{-}-\mathrm{N}$ before and after the experiment (Table 3, Fig. 1). Compared with their initial concentrations, the final removal rates of TP contents in the control and combined treatments were $22.9 \%$ and $71.6 \%$, respectively; the removal rates of $\mathrm{PO}_{4}^{3-} \mathrm{-P}$ in the control and combined treatments were $-28.3 \%$ and $53.6 \%$, respectively; the removal rates of $\mathrm{TN}$ contents were $32.6 \%$ and $39.9 \%$, respectively; the removal rates of $\mathrm{NH}_{4}^{+}-\mathrm{N}$ were $5.5 \%$ and $41.0 \%$, respectively; the removal rates of $\mathrm{NO}_{3}^{-}-\mathrm{N}$ were $-418.2 \%$ and $-548.9 \%$, respectively; the removal rates of $\mathrm{NO}_{2}^{-}-\mathrm{N}$ were $0 \%$ and $-12.5 \%$, respectively.

The results of statistical analysis indicate that the mean concentrations of TP and $\mathrm{PO}_{4}^{3-}-\mathrm{P}$ in the combined treatment group ( 0.234 and $0.193 \mathrm{mg} / \mathrm{L}$, respectively) were significantly lower than those of the control group $(\mathrm{P}<0.05)$. In addition, the mean concentrations of water $\mathrm{TN}, \mathrm{NO}_{3}^{-}-\mathrm{N}, \mathrm{NO}_{2}^{-}-\mathrm{N}$, and $\mathrm{NH}_{4}^{+}-\mathrm{N}$ in the

Table 3. Summary of results of ANOVA analysis of variance on environmental variables.

\begin{tabular}{|c|c|c|c|c|}
\hline \multirow{2}{*}{ Dependent variable } & \multicolumn{2}{|c|}{ Treatment } & \multicolumn{2}{c|}{ Time } \\
\cline { 2 - 5 } & $T$ & $p$ & $F_{3,62}=9.326$ & $<$ \\
\hline TP in overlying water & $F_{1,62}=18.599$ & $<0.05$ & $F_{3,62}=11.170$ & $<0.05$ \\
\hline $\mathrm{PO}_{4}{ }^{3-}-\mathrm{P}$ in overlying water & $F_{1,62}=11.079$ & $<0.05$ & $F_{3,62}=49.179$ & $<0.05$ \\
\hline $\mathrm{TN}$ in overlying water & $F_{1,62}=4.149$ & $>0.05$ & $F_{3,62}=5.642$ & $<0.05$ \\
\hline $\mathrm{NH}_{4}{ }^{+}$-N in overlying water & $F_{1,62}=0.217$ & $>0.05$ & $F_{3,62}=71.614$ & $<0.05$ \\
\hline $\mathrm{NO}_{3}{ }^{-}$-N in overlying water & $F_{1,62}=22.145$ & $<0.05$ & $F_{3,62}=159.860$ & $<0.05$ \\
\hline $\mathrm{NO}_{2}{ }^{-}-\mathrm{N}$ in overlying water & $F_{1,62}=32.644$ & $>0.05$ & $F_{3,62}=8.051$ & $<0.05$ \\
\hline TP in pore water & $F_{1,62}=0.135$ & $>0.05$ & $F_{3,62}=3.462$ & $<0.05$ \\
\hline TN in pore water & $F_{1,62}=7.639$ & $<0.05$ & $<0.05$ \\
\hline
\end{tabular}



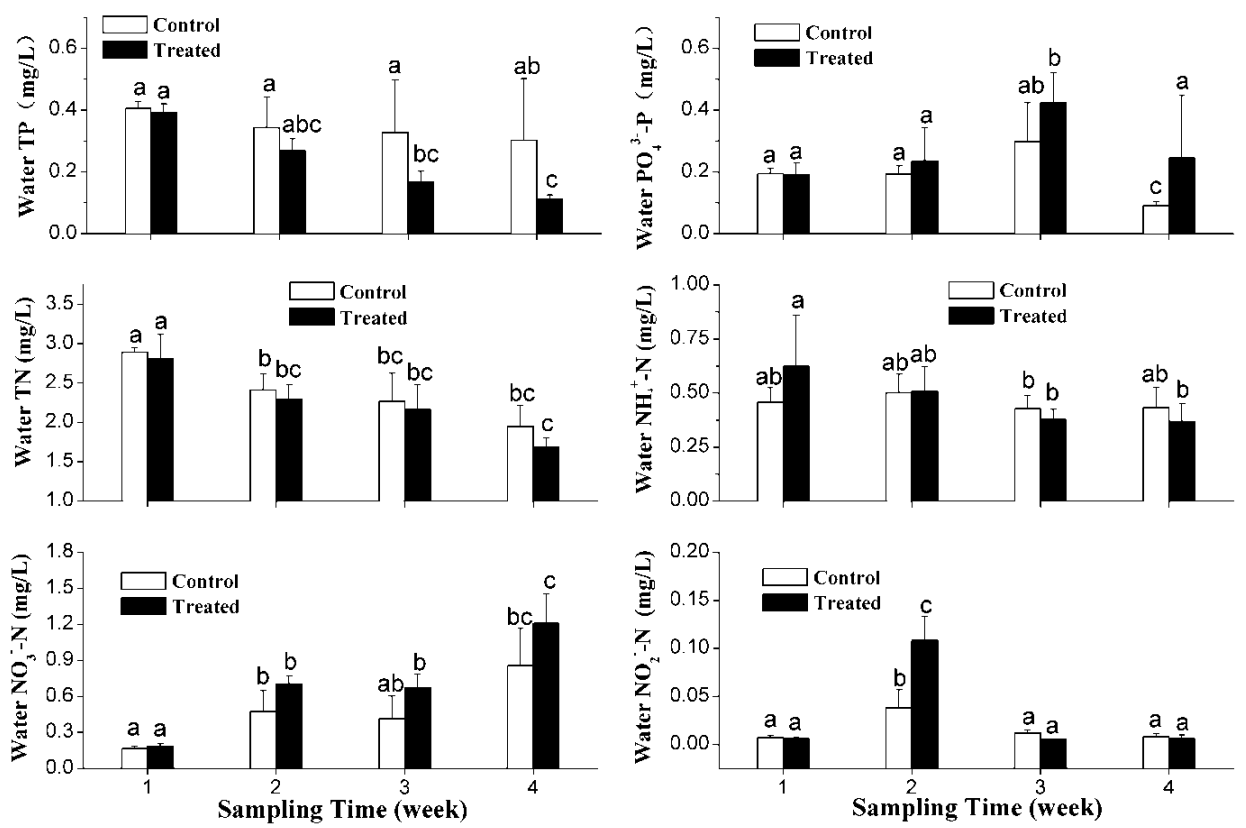

Fig. 1. Temporal variations of $\mathrm{TP}, \mathrm{PO}_{4}{ }^{3-} \mathrm{P}, \mathrm{TN}, \mathrm{NH}_{4}{ }^{+}-\mathrm{N}, \mathrm{NO}_{3}^{-}-\mathrm{N}$, and $\mathrm{NO}_{2}^{-}-\mathrm{N}$ concentrations in the overlying water.

combined treatment group were significantly different from those of the control group $(P<0.05)$. The mean $\mathrm{TN}$ concentration in the combined treatment group $(2.24 \mathrm{mg} / \mathrm{L})$ was significantly lower than in the control group $(2.38 \mathrm{mg} / \mathrm{L}, P<0.05)$, while the mean concentrations of $\mathrm{NO}_{3}^{-}-\mathrm{N}$ and $\mathrm{NO}_{2}^{-}-\mathrm{N}(0.692$ and $0.031 \mathrm{mg} / \mathrm{L}$, respectively) in the combined treatment group were significantly higher than those of the control group $(0.478$ and $0.016 \mathrm{mg} / \mathrm{L}$, respectively, $P<0.05)$.

\section{Changes in TN and TP Contents in the Pore Water}

Pore water TP and TN contents in the combined treatment group increased whereas those of the control group first decreased and then increased (Fig. 2). Compared with their initial concentrations, the pore water TP concentration in the control and combined treatment groups increased by $12.2 \%$ and $68.1 \%$, respectively; the concentrations of pore water TN increased by $6.9 \%$ and $24.1 \%$, respectively. The results of statistical analysis indicate that the mean TN concentration in the pore water in the combined treatment group $(9.518 \mathrm{mg} / \mathrm{L})$ was significantly lower than that in the control group $(10.425 \mathrm{mg} / \mathrm{L}, P<0.05)$. There was no significant difference in the mean TP concentrations between the control and combined treatment groups $(P>0.05)$, which were 0.589 and $0.598 \mathrm{mg} / \mathrm{L}$, respectively (Table 3 ).

Changes in Dehydrogenase, Urease, and Phosphatase Activities in the Sediments

Compared with their values before the experiment, the enzyme activity of dehydrogenase and phosphatase in the control and combined treatments were both decreased while urease activity increased (Fig. 3). The results of statistical analysis indicate that there
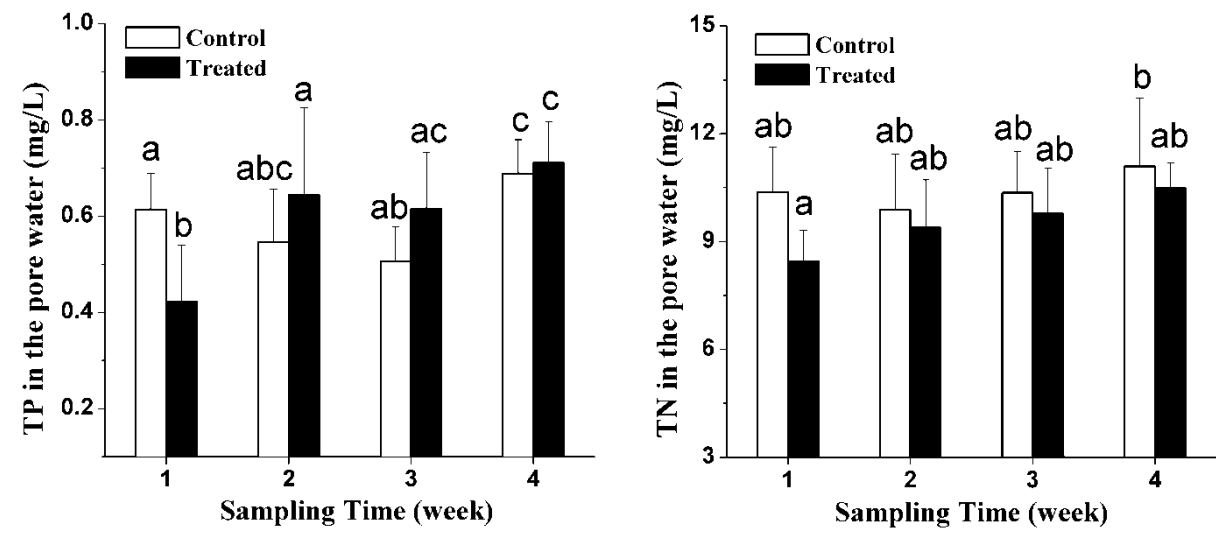

Fig. 2. Temporal variations of TP and TN contents in the pore water. 


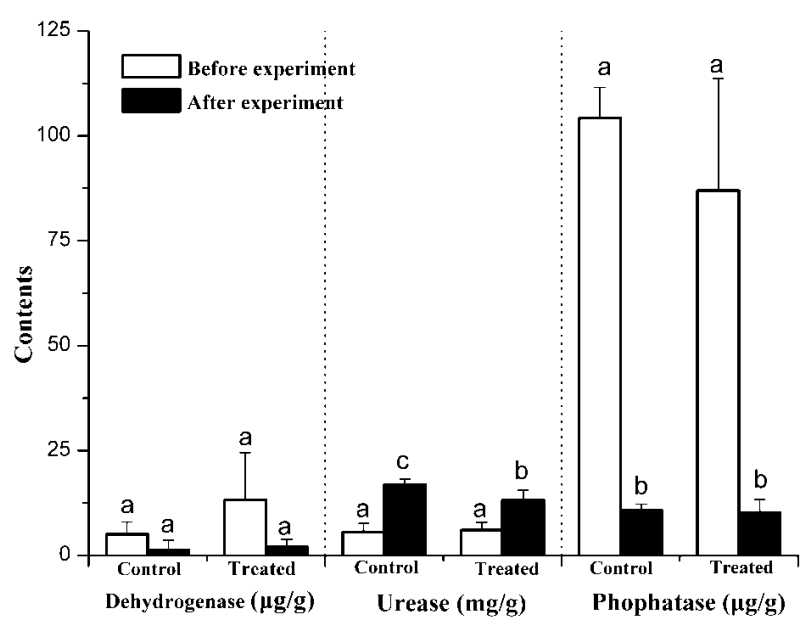

Fig. 3. Changes in dehydrogenase, urease, and phosphatase activity before and after the experiment.

were no significant differences in the contents of dehydrogenase, urease, and phosphatase between the control and combined treatment groups before treatment $(P>0.05)$. After treatment, the urease and phosphatase contents in the two groups were still not significantly different $(P>0.05)$, but the urease content in the control group was significantly higher than that in the combined group $(P<0.05)$.

Change of $\mathrm{N}$ and P Contents in the Overlying Water,

Macrophytes, and Sediments in the Combined Biological Restoration Treatment

As shown in Table 4, the concentrations of overlying water TP and TN in the combined treatment group decreased after the experiment. According to the experimental water volume, the decrements of TP and $\mathrm{TN}$ in the overlying water were 941.6 and $235.2 \mathrm{mg}$, respectively. Similarly, by measuring the dry weight, $\mathrm{TP}$, and TN contents of sediments before and after the experiment, the increments of $\mathrm{TP}$ and $\mathrm{TN}$ in the sediments were $1,344.0 \mathrm{mg}$ and $1,632.0 \mathrm{mg}$, respectively.
In addition, we also collected the macrophytes of the combined treatment group at the end of the experiment. Through determining the fresh weight, moisture content, and TP and TN contents per unit dry weight of submerged macrophytes before and after the experiment, the increments of TP and TN in the macrophytes were estimated. The results showed that TP and TN in the macrophytes increased by $539.6 \mathrm{mg}$ and $348.3 \mathrm{mg}$ after treatment, respectively. Based on the mass conservation principle, the changes of TP and TN in other ways were $942.0 \mathrm{mg}$ and $1,745.1 \mathrm{mg}$, respectively.

\section{Discussion}

\section{Mechanisms of Combined Biological Restoration Measure for Water P Removal}

$\mathrm{P}$ is one of the key nutrient factors for phytoplankton growth. However, excessive P input is the main cause inducing eutrophication in water bodies [24]. Effective reduction of external and internal $\mathrm{P}$ load is an important premise of using biological restoration measures to restore eutrophic water $[15,25]$. Our experimental results showed that the combined biological restoration measure effectively reduced $\mathrm{P}$ load in water. The mean TP concentration in the combined treatment group $(0.234 \mathrm{mg} / \mathrm{L})$ decreased by $31.98 \%$ compared with that in the control group $(0.344 \mathrm{mg} / \mathrm{L})$. Past studies have shown that both the microbial metabolism and the biological activity of aquatic organisms including bivalves, fish, and macrophytes have important effects on P exchange at the water-sediments interface [26-27].

In our experiment, due to the weight reduction of some silver carp and bivalves in the combined treatment group, the assimilation and absorption effects of silver carp and bivalves on nutrient $\mathrm{P}$ is limited. So it is not the main mechanism of water $\mathrm{P}$ removal. Moreover, the bioturbation of fish and bivalves could promote the $P$ release from sediments into the water $[11,28]$. In our experiment, the increase of $\mathrm{PO}_{4}^{3-} \mathrm{P}$ in the overlying water and higher TP content in the pore water indicate

Table 4. Changes of TN and TP contents in water, macrophytes, and sediments.

\begin{tabular}{|c|c|c|c|c|c|c|}
\hline \multirow{4}{*}{$\mathrm{TP}$} & $\begin{array}{c}\text { Concentrations } \\
\text { (before experiment) }\end{array}$ & $\begin{array}{c}\text { Concentrations } \\
\text { (after experiment) }\end{array}$ & $\begin{array}{c}\text { Volume or Weight } \\
\text { (before experiment) }\end{array}$ & $\begin{array}{c}\text { Volume or Weight } \\
\text { (after experiment) }\end{array}$ & Difference \\
\cline { 2 - 7 } & Overlying Water & $0.39 \pm 0.03(\mathrm{mg} / \mathrm{L})$ & $0.11 \pm 0.01(\mathrm{mg} / \mathrm{L})$ & $840 \mathrm{~L}$ & $840 \mathrm{~L}$ & $-235.2 \mathrm{mg}$ \\
\cline { 2 - 8 } & Macrophytes & $6.70 \pm 0.08(\mathrm{mg} / \mathrm{g})$ & $4.90 \pm 0.11(\mathrm{mg} / \mathrm{g})$ & $16.92 \mathrm{~g}(\mathrm{DW})$ & $94.22 \mathrm{~g}(\mathrm{DW})$ & $+348.3 \mathrm{mg}$ \\
\cline { 2 - 8 } & Sediments & $1.41 \pm 0.12(\mathrm{mg} / \mathrm{g})$ & $1.44 \pm 0.05(\mathrm{mg} / \mathrm{g})$ & $48 \mathrm{~kg}$ & $48 \mathrm{~kg}$ & $+1,632.0 \mathrm{mg}$ \\
\hline \multirow{4}{*}{$\mathrm{TN}$} & Others & - & - & - & - & $-1,745.1 \mathrm{mg}$ \\
\cline { 2 - 8 } & Overlying Water & $2.81 \pm 0.31(\mathrm{mg} / \mathrm{g})$ & $1.69 \pm 0.12(\mathrm{mg} / \mathrm{g})$ & $840 \mathrm{~L}$ & $840 \mathrm{~L}$ & $-941.6 \mathrm{mg}$ \\
\cline { 2 - 8 } & Macrophytes & $6.31 \pm 0.41(\mathrm{mg} / \mathrm{g})$ & $6.86 \pm 0.50(\mathrm{mg} / \mathrm{g})$ & $16.92 \mathrm{~g}(\mathrm{DW})$ & $94.22 \mathrm{~g}(\mathrm{DW})$ & $+539.6 \mathrm{mg}$ \\
\cline { 2 - 8 } & Sediments & $3.20 \pm 0.32(\mathrm{mg} / \mathrm{g})$ & $3.22 \pm 0.32(\mathrm{mg} / \mathrm{g})$ & $48 \mathrm{~kg}$ & $48 \mathrm{~kg}$ & $+1,344.0 \mathrm{mg}$ \\
\hline
\end{tabular}


that nutrient $\mathrm{P}$ has the potential of releasing from sediments into the water. However, compared with the sediment TP contents before and after treatment, it was found that the sediment TP content in the combined treatment group increased by $1,632 \mathrm{mg}$, which was 6.94 times of the decrement of water TP content. The biodeposition of particulate $\mathrm{P}$ in water caused by the grazing of silver carp and bivalves may be a reason why the content of water P did not increase. Previous studies have shown that silver carp and bivalves could promote the removal of water nutrients by grazing on suspended particles or algae and then excreting food residue or feces at the sediment surfaces [29-30]. When this transfer rate is greater than the release rate of nutrients from sediments to water, the water nutrient load will decrease and the eutrophication process will be slowed down. On the contrary, it will accelerate the process of water eutrophication. Thus, in this study, the nutrient transfer from water to the sediments was one of the main mechanisms for the removal of water P load.

In addition to the above mechanisms, our results showed that the assimilation and absorption of submerged macrophytes was also an important reason for water $\mathrm{P}$ load removal. Based on the mass conservation principle, the estimated $\mathrm{P}$ budget results of each experimental material in the combined biological restoration experimental systems showed that the TP absorbed by submerged macrophytes from the water and sediments is 1.48 times of the decrement of the overlying water TP. The importance effects of submerged macrophytes on migration and transformation of water nutrients in ecosystems have gained widespread attention, and the replanting submerged macrophytes technology has been applied to restore eutrophic waterbodies worldwide [2, 31]. In addition to the assimilation and absorption of nutrients from the water and sediments, submerged macrophytes could also promote the sedimentation of suspended particles in the water and reduce the sediment resuspension [32]. Furthermore, the replanting of submerged macrophytes could decrease the ability of $\mathrm{P}$ desorption on the sediments through affecting the contents of organic matter, $\mathrm{Ca}, \mathrm{Fe}$, and $\mathrm{Al}$ in sediments [33].

Dehydrogenase, which plays the role of hydrogen transfer, can promote the dehydrogenation of carbohydrates, organic acids, and other organic matter in the sediments; phosphatase can catalyze the hydrolysis of a phosphomonoester and the creation of a phosphate ion. To some extent, the activities of these two enzymes could reflect the transformation process of nutrient $\mathrm{P}$ in the sediments. In our experiment, the dehydrogenase and phosphatase activities decreased after treatment. The decrease of these enzyme activities may be caused by the changes of physical and chemical conditions. However, many researchers have found that the phosphatase activity is positive correlation with the removal rate of TP [34]. Thus, the microbial metabolism had no significant effects on the removal of water P load in our experiment, and more studies on the role of enzymes in the combined biological restoration measures are still needed. Compared with the control group, the concentration of $\mathrm{PO}_{4}^{3-}-\mathrm{P}$ in the combined treatment group increased significantly. This may be due to the biodeposition of bivalves in our experiment. Previous studies have shown that the biological activity of benthic animals could release nutrients into water $[25,35]$. Furthermore, the filtration, digestion, and excretion of silver carp and bivalves on water-suspended particles may also promote the transformation of water organic P to inorganic P [36]. In summary, in this study, the microbial metabolism played a limited role in the removal of water $\mathrm{P}$ load.

\section{Mechanisms of Combined Biological Restoration Measure for Water N Removal}

$\mathrm{N}$ is another important nutrient element causing eutrophication of waterbodies. After more than one month of treatment, the TN in the overlying water in the combined biological restoration group was effectively reduced and significantly lower than that in the control group. Similar to the removal mechanisms of $\mathrm{P}$ in the overlying water, the potential mechanisms of water $\mathrm{N}$ removal in our experiment included microbial metabolism, and the assimilation, absorption, and decomposition of aquatic organisms.

At the beginning of our experiment, the sums of $\mathrm{NH}_{4}^{+}-\mathrm{N}, \mathrm{NO}_{3}^{-}-\mathrm{N}$, and $\mathrm{NO}_{2}^{-}-\mathrm{N}$ concentrations in the control and combined treatment group were 0.63 and $0.81 \mathrm{mg}$, respectively, accounting for $21.7 \%$ and $29.0 \%$ of their TN contents. So the $\mathrm{N}$ in the water mainly existed in the forms of organic or particulate $\mathrm{N}$ at the beginning of the experiment. By the end of the experiment, the sums of three forms of $\mathrm{N}$ concentrations in the control and combined biological restoration groups were 1.293 and $1.580 \mathrm{mg}$, accounting for $66.4 \%$ and $93.6 \%$ of their $\mathrm{TN}$ contents, respectively, and the $\mathrm{N}$ in the water mainly existed in the form of $\mathrm{NO}_{3}^{-}-\mathrm{N}$. The results showed that the decrease of $\mathrm{TN}$ in the combined biological restoration group was caused by the removal of organic or particulate $\mathrm{N}$ in the water.

The ammonification, nitrification, and denitrification of microorganisms all play an important role in the transformation of different forms of $\mathrm{N}$ in water. At the beginning and end of our experiment the contents of $\mathrm{NH}_{4}^{+}-\mathrm{N}$ and $\mathrm{NO}_{2}^{-}-\mathrm{N}$ between the control and combined biological restoration groups had no significant difference. But the increase of $\mathrm{NO}_{3}^{-}-\mathrm{N}$ indicates that the combined biological restoration measure promoted the microbial nitrification process, which may be due to the fact that submerged macrophytes could release the oxygen content from roots [37]. Urease catalyzes the hydrolysis of urea into carbon dioxide and ammonia, and its activity represents the conversion of organic $\mathrm{N}$ to inorganic $\mathrm{N}$. Our results showed that the urease activities increased in both the control and combined biological restoration groups at the end of the experiment, which promoted the transformation of 
organic $\mathrm{N}$ to inorganic $\mathrm{N}$ in the sediments and increased the possibility of the $\mathrm{N}$ release. However, the monitoring results of water quality and sediment TN content showed that the TN contents increased in the sediments while decreasing in the water. One possible reason is that the biodeposition of silver carp and bivalves accelerated the transformation of particulate $\mathrm{N}$ from water into the sediments [29-30]. The silver carp and bivalves could filter suspended particles and algae from water, and then excrete the feces or pseudofeces into the water or the sediment surface. The increases of TN contents in the pore water and sediments also confirmed that the migration and transformation of particle $\mathrm{N}$ from water into the sediments was an important mechanism for removing the overlying water $\mathrm{TN}$.

In addition to the above reasons, our experiment results showed that the replanting of submerged macrophytes was another one of the important mechanisms of the overlying water TN removal. First of all, the effects of assimilation and absorption of submerged macrophytes on nutrient $\mathrm{N}$ from water and sediments have been proven in many studies [38-39]. Similar results were also obtained in our experiment. The $\mathrm{N}$ content in the macrophytes increased by $539.6 \mathrm{~g}$, accounting for $57.3 \%$ of the decrement of the overlying water TN contents. Furthermore, submerged macrophytes could inhibit the release of $\mathrm{NH}_{4}^{+}-\mathrm{N}$ and $\mathrm{NO}_{3}^{-} \mathrm{-N}$ from sediments into the water [40]. Our monitoring results showed that the increase of the urease activity promoted the conversion of sediment organic $\mathrm{N}$ to $\mathrm{NH}_{4}^{+}-\mathrm{N}$, and thereby increased the possibility of $\mathrm{NH}_{4}^{+}-\mathrm{N}$ release from sediments into the water. However, the statistical analysis showed that the $\mathrm{NH}_{4}^{+}-\mathrm{N}$ in the overlying water in the combined biological restoration group had no significant difference from that in the control group. In addition, the higher $\mathrm{NO}_{3}^{-}-\mathrm{N}$ and $\mathrm{NO}_{2}^{-}-\mathrm{N}$ in the combined biological restoration group may be because the oxygen release from roots of macrophytes strengthened the microbial nitrification process of $\mathrm{NH}_{4}^{+}-\mathrm{N}$ [41]. Moreover, submerged macrophytes can weaken the resuspension of sediments caused by silver carp and bivalves [42]. Accordingly, the migration of nutrients from sediments into the water was also one of the possible reasons for the removal of water $\mathrm{N}$ in the combined biological restoration group.

\section{Conclusions}

1) The combined biological restoration measure of introducing filter-feeding bivalves, stocking planktivorous fish, and replanting submerged macrophytes could effectively control the water nutrients.

2) The assimilation and absorption of submerged macrophytes and the nutrient transformation from water to sediments are the main mechanisms of the combined biological restoration measure to reduce water $\mathrm{N}$ and $\mathrm{P}$ nutrients.

\section{Acknowledgements}

This study was supported by grants from the National Science and Technology Support Program of China's 12th Five-Year Plan (No. 2012BAJ21B03-004), the National Natural Science Foundation of China (No. 51178452), the Major Science and Technology Program for Water Pollution Control and Treatment of China's 12th Five-Year Plan (No. 2012ZX07101007005), and the Knowledge Innovation Program of the Chinese Academy of Sciences. The authors thank Profs. Yongyuan Zhang and Baoyuan Liu; Drs. Biyun Liu, Enrong Xiao, Dong $\mathrm{Xu}$, and Junmei $\mathrm{Wu}$; and Ms. Liping Zhang for experimental assistance and paper preparation (Institute of Hydrobiology, Chinese Academy of Sciences).

\section{References}

1. LE C., ZHA Y., LI Y., SUN D., LU H., YIN B. Eutrophication of lake waters in China: cost, causes, and contol. Envir. Manage. 45, 662, 2010.

2. JEPPESEN E., SØNDERGAARD M., LAURIDSEN T.L., DAVIDSON T.A., LIU Z., MAZZEO N., MEERHOFF M. Biomanipulation as a restoration tool to combat eutrophication: recent advances and future challenges. Advances in Ecological Research. 47, 411, 2012.

3. YI C., GUO L., NI L., LUO C. Silver carp exhibited an enhanced ability of biomanipulation to control cyanobacteria bloom compared to bighead carp in hypereutrophic Lake Taihu mesocosms. Ecological Engineering. 89, 7, 2016.

4. WAAJEN G.W., VAN BRUGGEN N.C., PIRES L.M.D., LENGKEEK W., LÜRLING M. Biomanipulation with quagga mussels (Dreissena rostriformis bugensis) to control harmful algal blooms in eutrophic urban ponds. Ecological Engineering. 90, 141, 2016.

5. SØNDERGAARD M., JOHANSSON L.S., LAURIDSEN T.L., JØRGENSEN T.B., LIBORIUSSEN, L., JEPPESEN, E. Submerged macrophytes as indicators of the ecological quality of lakes. Freshwater Biology. 55 (4), 893, 2010.

6. ZENG LEI, HE FENG, ZHANG YI, LIU BIYUN, DAI ZHIGANG, ZHOU QIAOHONG, WU ZHENBIN. How submerged macrophyte restoration promotes a shift of phytoplankton community in a shallow subtropical lake. 26 (3), 1363, 2017.

7. GULATI R.D., PIRES L.M.D., VAN DONK E. Lake restoration studies: failures, bottlenecks and prospects of new ecotechnological measures. Limnologica-Ecology and Management of Inland Waters. 38 (3), 233, 2008.

8. ZHANG X, XIE P, HUANG X. A review of nontraditional biomanipulation. The Scientific World Journal. 8, 1184, 2008.

9. HOBBS W.O., HOBBS J.M.R., LA FRANCOIS T., ZIMMER K.D., THEISSEN K.M., EDLUND M.B., CARLSON T.J. A 200-year perspective on alternative stable state theory and lake management from a biomanipulated shallow lake. Ecological Applications. 22 (5), 1483, 2012.

10. ZHANG X., LIU Z., JEPPESEN E., TAYLOR W.D. Effects of deposit-feeding tubificid worms and filter-feeding bivalves on benthic-pelagic coupling: implications for the 
restoration of eutrophic shallow lakes. Water Research. 50, 135, 2014

11. ZHANG X., LIU Z., JEPPESEN E., TAYLOR W.D., RUDSTAM L.G. Effects of benthic-feeding common carp and filter-feeding silver carp on benthic-pelagic coupling: Implications for shallow lake management. Ecological Engineering. 88, 256, 2016.

12. WANG L., HE F., SUN J., HU Y., HUANG T., ZHANG Y., WU Z. Effects of three biological control approaches and their combination on the restoration of eutrophicated waterbodies. Limnology. 18 (3) 301, 2017.

13. SØNDERGAARD M., LAURIDSEN T.L., JOHANSSON L.S., JEPPESEN E. Nitrogen or phosphorus limitation in lakes and its impact on phytoplankton biomass and submerged macrophyte cover. Hydrobiologia. 795 (1), 35, 2017.

14. ARMITAGE A.R., FRANKOVICH T.A., FOURQUREAN J.W. Long-term effects of adding nutrients to an oligotrophic coastal environment. Ecosystems. 14 (3), 430, 2011.

15. SMITH V.H., WOOD S.A., MCBRIDE C.G., ATALAH J., HAMILTON D.P., ABELL J. Phosphorus and nitrogen loading restraints are essential for successful eutrophication control of Lake Rotorua, New Zealand. Inland Waters. 6 (2), 273, 2016.

16. NIZZOLI D., WELSH D.T., VIAROLI P. Seasonal nitrogen and phosphorus dynamics during benthic clam and suspended mussel cultivation. Marine pollution bulletin. 62 (6), 1276, 2011

17. LACOSTE E., GUEGUEN Y., LE MOULLAC G., KOUA M.S., GAERTNER-MAZOUNI N. Influence of farmed pearl oysters and associated biofouling communities on nutrient regeneration in lagoons of French Polynesia. Aquaculture Environment Interactions. 5 (3), 209, 2014.

18. PAN G., YANG B., WANG D., CHEN H., TIAN B.H., ZHANG M.L., CHEN J. In-lake algal bloom removal and submerged vegetation restoration using modified local soils. Ecological Engineering. 37 (2), 302, 2011.

19. ZHANG S.H., GUO L., CAO J.Y., CHANG J.J. Allelopathic activities of three emergent macrophytes on several monospecific cyanobacterial species and natural phytoplankton assemblages. Pol. J. Environ. Stud. 24 (1), 397, 2015.

20. SINSABAUGH R.L., FOLLSTAD SHAH J.J. Ecoenzymatic stoichiometry and ecological theory. Annual Review of Ecology, Evolution, and Systematics. 43, 313, 2012.

21. KOLEHMAINEN R.E., KORPELA J.P., MÜNSTER U., PUHAKKA J.A., TUOVINEN O.H. Extracellular enzyme activities and nutrient availability during artificial groundwater recharge. Water research. 43 (2), 405, 2009.

22. HILL B.H., ELONEN C.M., JICHA T.M., BOLGRIEN D.W., MOFFETT M.F. Sediment microbial enzyme activity as an indicator of nutrient limitation in the great rivers of the Upper Mississippi River basin. Biogeochemistry. 97 (23), 195, 2010

23. NATIONAL BUREAU OF ENVIRONMENT PROTECTION EDITORIAL COMMITTEE OF WATER AND WASTE WATER MONITORING ANALYTICAL METHODS (ED.). Water and Wastewater Monitoring Analysis Method, $4^{\text {th }}$ ed. Chinese Environment Science Press, Beijing, China. 2002.

24. CONLEY D.J., PAERL H.W., HOWARTH R.W., BOESCH D.F., SEITZINGER S.P., KARL E., GENE E. Controlling eutrophication: nitrogen and phosphorus. Science. 123, 1014, 2009
25. ZAMPARAS M., ZACHARIAS, I. Restoration of eutrophic freshwater by managing internal nutrient loads. A review. Science of the Total Environment. 496, $551,2014$.

26. HUMAN L.R., SNOW G.C., ADAMS J.B., BATE G.C., YANG S.C. The role of submerged macrophytes and macroalgae in nutrient cycling: A budget approach. Estuarine, Coastal and Shelf Science. 154, 169, 2015.

27. MURPHY A.E., ANDERSON I.C., SMYTH A.R., SONG, B., LUCKENBACH M.W. Microbial nitrogen processing in hard clam (Mercenaria mercenaria) aquaculture sediments: the relative importance of denitrification and dissimilatory nitrate reduction to ammonium (DNRA). Limnology and Oceanography. 61 (5), 1589, 2016.

28. SCHMITZ O.J., HAWLENA D., TRUSSELL G.C. Predator control of ecosystem nutrient dynamics. Ecology Letters. 13 (10), 1199, 2010.

29. XIA B., SUN Z., GAO Q.F., DONG S., WANG F. Carbon, nitrogen and phosphorus budgets of silver carp Hypophthalmichthys molitrix with the co-culture of grass carp Ctenopharyngodon idella. Aquaculture Environment Interactions. 8, 453, 2016.

30. ATTAYDE J.L., VAN NES E.H., ARAUJO A.I., CORSO G., SCHEFFER M. Omnivory by planktivores stabilizes plankton dynamics, but may either promote or reduce algal biomass. Ecosystems. 13, 410, 2010.

31. ZENG L., HE F., DAI Z., XU D., LIU B., ZHOU Q., WU Z. Effect of submerged macrophyte restoration on improving aquatic ecosystem in a subtropical, shallow lake. Ecological Engineering. 106, 578, 2017.

32. ROVIRA A., ALCARAZ C., TROBAJO R. Effects of plant architecture and water velocity on sediment retention by submerged macrophytes. Freshwater Biology. 61 (5), 758, 2016.

33. WANG S., JIN X., ZHAO H., ZHOU X., WU F. Effects of Hydrilla verticillata on phosphorus retention and release in sediments. Water, Air, and Soil Pollution. 181 (1-4), 329, 2007.

34. WU S., CHANG J., DAI Y., WU Z., LIANG W. Treatment performance and microorganism community structure of integrated vertical-flow constructed wetland plots for domestic wastewater. Environmental Science and Pollution Research. 20 (6), 3789, 2013.

35. NEWELL R.I., FISHER T.R., HOLYOKE R.R., CORNWELL J.C. Influence of eastern oysters on nitrogen and phosphorus regeneration in Chesapeake Bay, USA. The comparative roles of suspension-feeders in ecosystems. 93, 2005.

36. SINGH N., GUPTA P.K., SCHAUS M.H. Excretion of nitrogen and phosphorus by Gambusia holbrooki. International Journal. 3 (11), 145, 2015.

37. VAN HULLE S.W.H., VANDEWEYER H.J.P., MEESSCHAERT B.D., VANROLLEGHEM P.A., DEJANS P., DUMOULIN A. Engineering aspects and practical application of autotrophic nitrogen removal from nitrogen rich streams. Chemical Engineering Journal. 162 (1), 1,2010

38. WU Z.B. Macrophyte and aquatic ecological restoration. Beijing: Science Press, 2011.

39. DAI Y., JIA C., LIANG W., HU S., WU Z. Effects of the submerged macrophyte Ceratophyllum demersum L. on restoration of a eutrophic waterbody and its optimal coverage. Ecological Engineering. 40, 113, 2012.

40. WANG S.R., JIN X.C., CUI Z., YAN C.Z., BU Q.Y., ZHAO H.C., CHU J.Z., ZHOU X.N. Effects of submerged plant on the concentrations of different nitrogen species in water- 
sediment interface. Environmental Chemistry. 25 (5), 533, 2006.

41. SZAJDAK L.W., GACA W. The influence of nitrogen on denitrification processes in soil under shelterbelt and adjoining cultivated field. Physical, chemical and biological processes in soils. Poznań. 225, 2010.
42. NURMINEN L., HORPPILA J. Life form dependent impacts of macrophyte vegetation on the ratio of resuspended nutrients. Water Research. 43 (13), 3217, 2009. 